\title{
Placoid chorioretinopathiák szisztémás fertőzésekben
}

\author{
Czakó Cecília dr. - Gergely Róbert dr., \\ Horváth Hajnalka dr. - Dohán Judit dr. - Kovács Illés dr. \\ Nagy Zoltán Zsolt dr. - Szepessy Zsuzsanna dr.
}

Semmelweis Egyetem, Általános Orvostudományi Kar, Szemészeti Klinika, Budapest

\begin{abstract}
Bevezetés és célkitüzés: Szisztémás fertőzésekhez társuló placoid chorioretinopathiák két esetének bemutatásán keresztül áttekinteni a szifilisz és a tuberkulózis szemészeti tüneteit, terápiás lehetőségeit, valamint felhívni a figyelmet az interdiszciplináris összefogásra ezen két betegség diagnosztikája és terápiája terén.

Módszer: Első esetünkben a 38 éves, második esetünkben a 47 éves nóbeteg bal szem látásromlása miatt jelentkezett intézményünkben. Mindkét betegnél a szemfenéki vizsgálat során macula luteát magában foglaló, a teljes hátsó pólust érintő placoid elváltozás volt látható. Az első betegnél az infektológiai szerológiai vizsgálat során Treponema pallidum-IgM-pozitivitás, a második beteg esetében QuantiFERON-pozitivitás igazolódott.

Eredmények: Az anamnesztikus adatok, a jellegzetes klinikai kép, a pozitív laboratóriumi vizsgálatok és a terápiára adott kedvező válasz alapján első esetünkben ocularis szifilisz, második esetünkben ocularis tuberkulózis diagnózisát állapítottuk meg. Mindkét esetben az adekvát terápia hatására a gyulladásos tünetek csökkentek, és a betegek látóélessége javult.

Következtetés: A szemfenéki placoid laesiók szisztémás fertőzések első tünetei lehetnek, így a szemészeti panaszok is fontos anamnesztikus adatként szolgálhatnak. A placoid chorioretinopathiák differenciáldiagnosztikája szempontjából döntő a fertőző szisztémás betegségek kimutatása vagy kizárása a betegségek eltérő terápiája miatt, amihez nélkülözhetetlen a szemészek szoros együttmúködése a társszakmák orvosaival.
\end{abstract}

Orv Hetil. 2018; 159(22): 863-869.

Kulcsszavak: placoid chorioretinopathia, tuberkulózis, szifilisz, gyulladás

\section{Placoid chorioretinopathy in systemic infections}

Introduction and aim: To present two cases of placoid chorioretinopathy (ocular syphilis and ocular tuberculosis) and underline the importance of differential diagnosis.

Method: Two young female patients presented with unilateral loss of vision. Fundus examination showed yellowish placoid lesions in the posterior pole in both cases.

Results: Performing fluorescein angiography and laboratory investigations, ocular syphilis was diagnosed in our first case and intraocular tuberculosis was diagnosed in our second case.

Conclusion: It is important to determine the etiology of the placoid choriaretinopathies due to the different prognosis and therapy and the exclusion of systemic diseases. A comprehensive evaluation of these patients is inevitable for the correct diagnosis and appropriate management.

Keywords: placoid chorioretinopathy, sepiginous chorioiditis, syphilis, tuberculosis

Czakó C, Gergely R, Horváth H, Dohán J, Kovács I, Nagy ZZs, Szepessy Zs. [Placoid chorioretinopathy in systemic infections]. Orv Hetil. 2018; 159(22): 863-869.

(Beérkezett: 2018. február 7.; elfogadva: 2018. március 12.)

\section{Rövidítések}

AIDS $=($ acquired immune deficiency syndrome $)$ szerzett immunhiányos tünetegyüttes; $\mathrm{APMPPE}=$ (acute posterior multifocal placoid pigment epitheliopathy) akut posterior multifoká- lis placoid pigmentepitheliopathia; ASPPC $=($ acute syphilitic posterior placoid chorioretinitis) akut szifiliszes posterior placoid chorioiditis; ATT $=$ antituberkulotikum; BCG $=$ Bacillus Calmette-Guérin; CMIA = chemiluminescence microparticle 
enzyme immunoassay; CMV = cytomegalovirus; $\mathrm{DNS}=$ dezoxiribonukleinsav; $\mathrm{EBV}=$ Epstein-Barr-vírus; FAF = fundus autofluoreszcencia; FLAG = fluoreszcens angiográfia; FTA-ABs = (fluorescent treponemal antibody absorption) fluoreszcens Treponema-antitest-abszorpció; HIV = humán immundeficientiavírus; $\mathrm{HSV}=$ herpes simplex vírus; $\mathrm{ICG}=$ indocianinzöld angiográfia; IGM = immunglobulin $\mathrm{M}$; $\mathrm{NE}=$ nemzetközi egység; OCT $=$ optikaikoherencia-tomográfia; OCTA = optikaikoherencia-tomográfiás angiográfia; $\mathrm{PCR}=$ (polymerase chain reaction) polimeráz-láncreakció; $\mathrm{PPM}=$ perzisztens placoid maculopathia; $\mathrm{RPR}=$ rapid plazmareagin; $\mathrm{SC}=$ serpiginosus chorioiditis; SLC = (serpiginosus-like choroiditis) serpiginosusszerú chorioiditis; tbc $=$ tuberkulózis; TPPA $=($ Treponema pallidum particle agglutination) Treponema pallidum-részecske-agglutináció; VDRL = (venereal diseases research laboratory) nemibetegség-kutató laboratórium; VZV = varicella-zoster vírus; $\mathrm{WHO}=$ (World Health Organization $)$ Egészségügyi Világszervezet

A placoid chorioretinopathiák heterogén szemészeti kórképek csoportját alkotják, melyet a szemgolyó hátsó pólusát érintő, multifokális gyulladásos folyamatok jellemeznek a retina külső rétegei, a retinalis pigmentepithelium és a chorioidea szintjében [1].

A betegség tünetei nem specifikusak, a leggyakrabban homályos látásról, úszkáló homályok és fényfelvillanások (photopsia) észleléséről, az egyenes vonalak görbüléséről (metamorphopsia) és centrális vagy paracentrális foltlátásról (scotoma) panaszkodnak a betegek. A jellegzetes klinikai kép különböző nagyságú, általában 1-2 papillányi multiplex vagy egységes sárgásfehér placoid foltok megjelenése a szemfenéken, melyek leginkább az éleslátás helyét, a macula luteát és a látóidegfő (papilla) környékét érintik [2].

A placoid chorioretinopathiák megjelenhetnek idiopathiás, izolált szemészeti megbetegedés formájában (fehérfolt, angolul white dot szindrómák), de előfordulhatnak szisztémás autoimmun és fertőzéses betegségek részeként, az utóbbi esetben a szemészeti érintettség a beteg első tüneteként is jelentkezhet. A betegségcsoport etiológiájának meghatározása döntő; a betegek alapos immu-

1. táblázat | Placoid chorioretinopathiák

\begin{tabular}{lll}
\hline $\begin{array}{l}\text { Izolált szemészeti } \\
\text { érintettség }\end{array}$ & Szisztémás érintettség \\
\hline White dot szindrómák & $\begin{array}{l}\text { Szisztémás fertőző } \\
\text { betegség }\end{array}$ & $\begin{array}{l}\text { Szisztémás autoim- } \\
\text { mun betegség }\end{array}$ \\
\hline APMPPE & Tuberkulózis: SLC & Sarcoidosis \\
\hline $\begin{array}{l}\text { Serpiginosus } \\
\text { chorioiditis }\end{array}$ & Szifilisz: ASPPC & \\
\hline Relentless chorioiditis & & \\
\hline PPM & & \\
\hline
\end{tabular}

APMPPE = akut posterior multifokális placoid pigmentepitheliopathia; ASPPC = akut szifiliszes placoid posterior chorioretinitis; PPM = posterior perzisztens maculopathia; $\mathrm{SLC}=$ serpiginosusszerü chorioiditis nológiai és infektológiai kivizsgálása nélkülözhetetlen a megfelelő terápia megkezdése céljából $[1,2]$. A placoid chorioretinopathiák típusait az 1. táblázat foglalja össze.

Jelen közleményünk célja két eset bemutatása, ahol a szemészeti panaszok hátterében felfedezett placoid chorioretinopathia a betegség első és egyetlen tüneteként jelentkezett. Az általános kivizsgálás és a gyors interdiszciplináris összefogás (bőrgyógyászok, pulmonológusok) során két, szisztémás fertőző betegség, első esetünkben szifilisz, második esetünkben pedig tuberkulózis igazolódott.

\section{Az első eset ismertetése}

A 38 éves nóbeteg bal szem látásromlása, centrális foltlátása miatt került intézetünkbe. Anamnézisében sem szemészeti, sem belgyógyászati betegség nem szerepelt. Szemészeti vizsgálatakor a legjobb korrigált látóélessége jobb szemén 1,0, bal szemén pedig 0,1 volt. Amsler-rács segítségével a bal szemén centrális scotoma volt kimutatható. Szemnyomása mindkét oldalon a normáltartományban volt. Réslámpás vizsgálat során mindkét oldalon békés elülső szegmentumot láttunk. Biomikroszkópos vizsgálat során a jobb oldalon ép fundust, a bal oldalon a maculát magában foglaló, a teljes hátsó pólust érintő

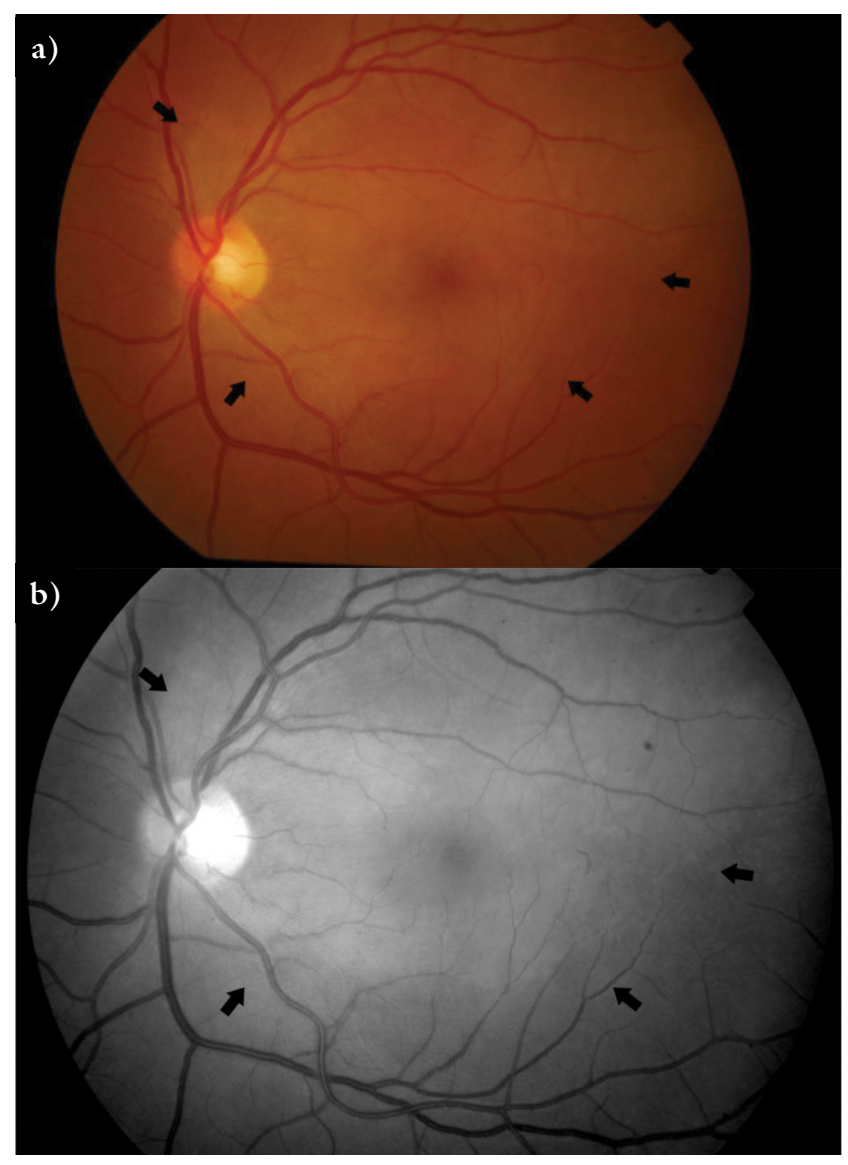

1. ábra $\quad$ A bal oldali szemfenéken a maculát magában foglaló, a teljes hátsó pólust érintő nagy, sárgásfehér, placoid, halvány szélű, öszszefolyó elváltozás látható (a) fundusfotó, b) vörösmentes kép - a fekete nyilak a laesio határait jelölik) 


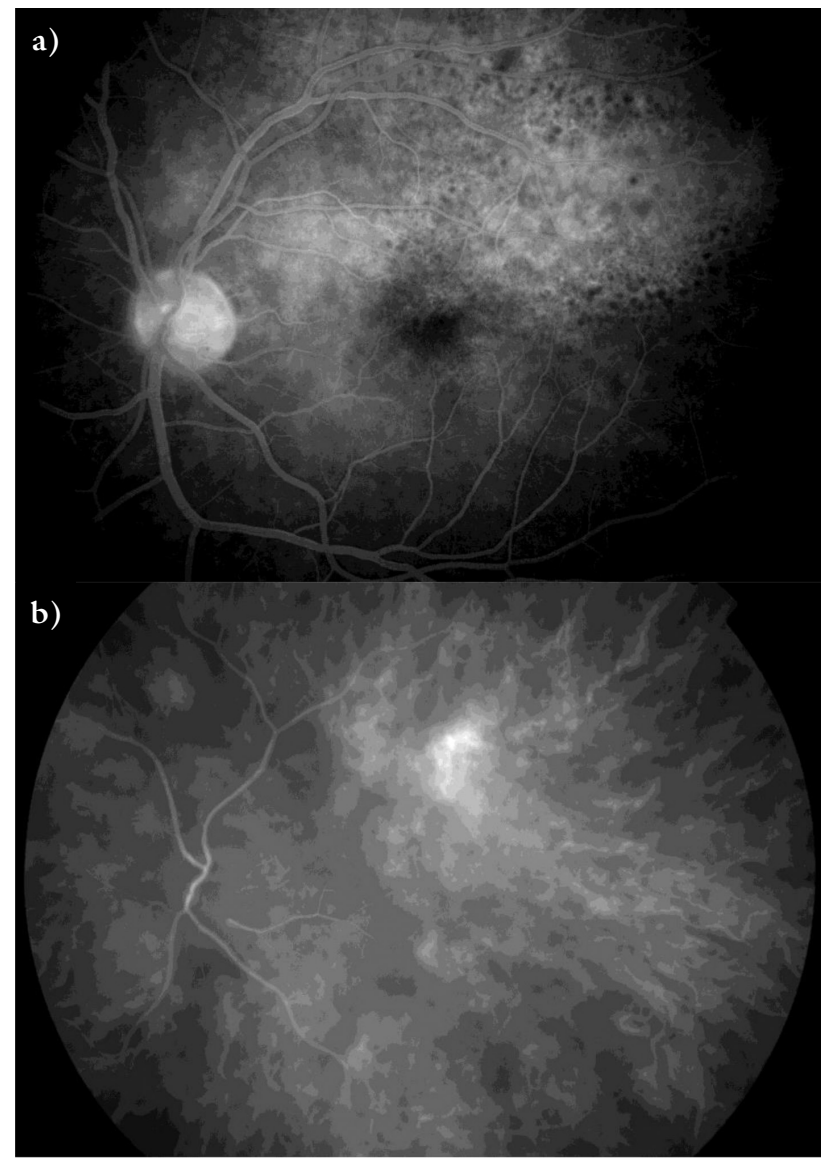

2. ábra

a) A fluoreszcens angiográfiás korai felvételen foltos, leopárdmin tás festéktelődés látható a placoid laesiónak megfelelően. b) Indocianinzöld angiográfiás felvételen a késói szakaszban a maculatáj felső részén festékszivárgás látható a laesiónak megfelelően

nagy, sárgásfehér, placoid, halvány szélű, összefolyó elváltozás volt megfigyelhető (1. ábra). Fluoreszcens angiográfiás vizsgálaton a placoid laesiónak megfelelően a korai felvételeken leopárdmintás festéktelődést $(2 / a$ ábra), indocianinzöld angiográfiás vizsgálaton a késői felvételeken festékszivárgást láttunk (2/b ábra). A macula OCT-vizsgálata során subretinalis folyadékot és a fotoreceptorréteg feltöredezettségét láttuk (3. ábra). A beteg általános kivizsgálása során rutin laborleletében eltérés nem volt. A tuberkulózis és sarcoidosis kizárása céljából végzett mellkas-röntgenvizsgálat nem mutatott kórosat, illetve az elvégzett QuantiFERON-TB-Goldteszt is negatív eredménnyel zárult. A beteg szerológiai vizsgálata során azonban Treponema pallidum-IgM-pozitivitás igazolódott. Más szerológiai laboreltérése nem volt kimutatható (Borrelia-, Toxoplasma-, EBV-, HSV1-, VZV-, HSV2-, CMV-, HIV-teszt eredménye negatív lett). A klinikai kép és a szerológiai eredmény alapján akut szifiliszes posterior placoid chorioiditist (ASPPC) diagnosztizáltunk. Betegünknél ezután neurológiai vizsgálat történt; a koponya-MR és liquorpunkciója eltérést nem mutatott. Szisztémás, intravénás penicillinterápiában részesült 3 héten keresztül, amelynek hatására bal szemén látóélessége javult, teljessé vált. A macula OCT-
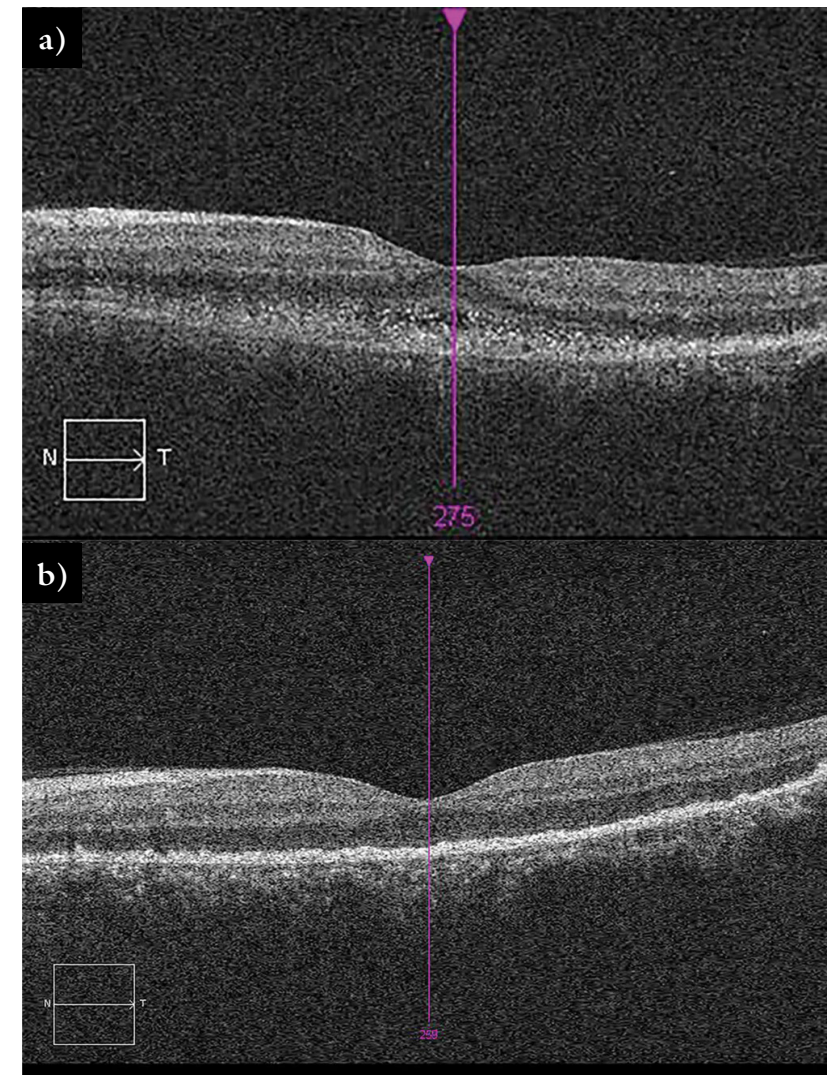

3. ábra

a) A macula-OCT-felvételen subretinalis folyadék és a fotoreceptorréteg feltöredezettsége látható. b) Penicillinterápia után 3 hónappal a macula-OCT-felvételen a subretinalis folyadék már nem látható; a fotoreceptorréteg feltöredezettsége továbbra is megfigyelhető

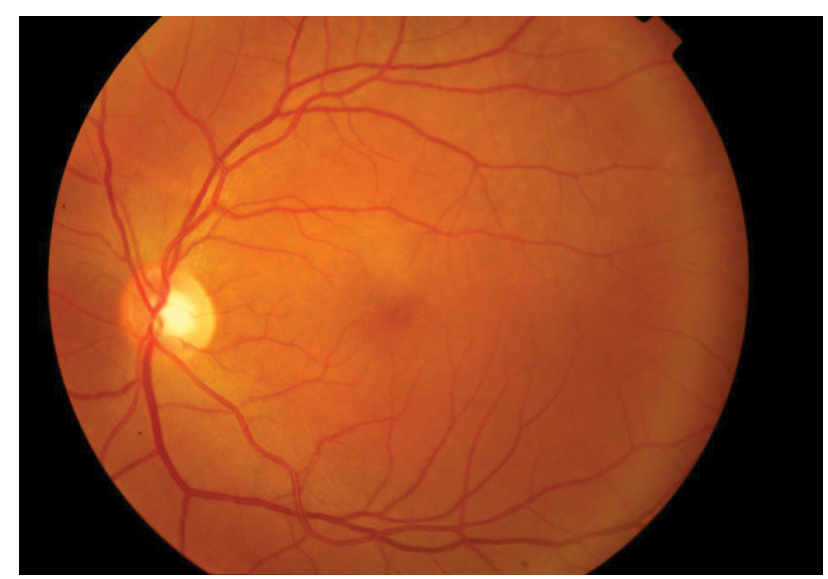

4. ábra

Penicillinterápia után 3 hónappal a szemfenéki placoid elváltozás megszűnt, a szemfenéki kép normalizálódott

vizsgálaton a subretinalis folyadék nem volt megfigyelhető. A szemfenéki eltérések 3 hónap után már nem voltak kimutathatók (4. ábra).

\section{A második eset ismertetése}

A 47 éves, afrikai származású nőbeteg bal szem egy hete fennálló látásromlásával jelentkezett intézményünkben. 
Anamnézisében hipertónián kívül egyéb szisztémás betegség nem volt ismert. A tíz éve Magyarországon élő beteg első megjelenését megelőzően két hónappal Kamerunban járt, környezetében testvéreinél tuberkulózis korábban előfordult. BCG-oltásban a beteg nem részesült. Első megjelenésekor legjobb korrigált látóélessége $1,0 / 0,15$ volt. A réslámpás vizsgálaton békés elülső szegmentum, a szemfenéken a hátsó póluson konfluáló, kissé elmosódott szélü, a macula csaknem teljes területét érintő, kiterjedt sárgásfehér placoid laesio volt látható (5. ábra). Macula-OCT-vizsgálaton a laesiónak megfelelően subretinalis folyadékot, a fotoreceptorréteg felszakadását, valamint a retinalis pigmentepithelium hiperreflektív megvastagodását láttuk (6. ábra). A fluoreszcens angiográfiás vizsgálat a placoid laesiónak megfelelően hipofluoreszcens blokkolást, szélein a későbbi felvételeken hiperfluoreszcens festődést mutatott (7. ábra). Az infektológiai szerológiai vizsgálat QuantiFERON-pozitivitást igazolt, míg más szerológiai eltérés nem volt kimutatható. A pulmonológiai konzílium során történt mellkasröntgenen kóros infiltrátum a tüdőben nem volt látható, de tekintettel a beteg szemészeti tüneteire, anamnézisére és QuantiFERON-pozitivitására, a pulmonológusok azonnal szisztémás antituberkulotikumos terápiát kezdtek (izoniazid, rifampicin, etambutol szájon át 3 hónapon keresztül). Két hónappal a terápia megkez-

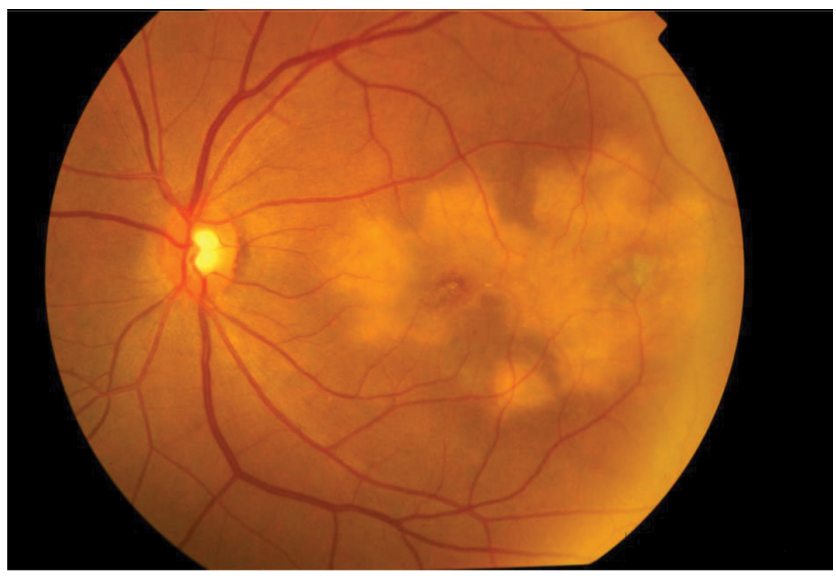

5. ábra

A bal oldali szemfenéken a hátsó póluson konfluáló, kissé elmosódott szélü, a macula csaknem teljes területét érintő, kiterjed sárgásfehér placoid laesio látható

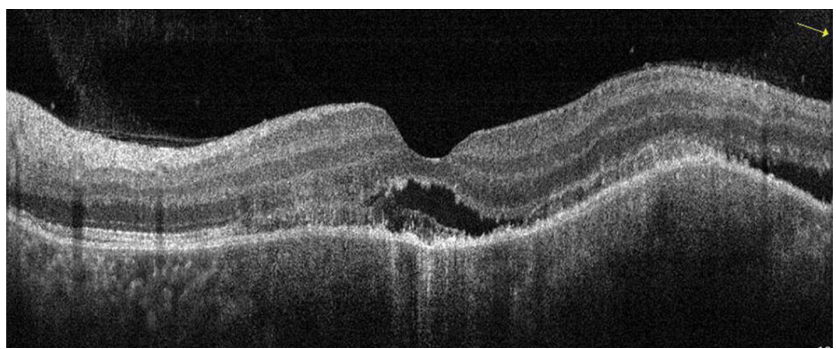

6. ábra

A macula-OCT-vizsgálaton subretinalis folyadék, a fotoreceptorréteg felszakadása, valamint a retinalis pigmentepithelium hiperreflektív megvastagodása látható
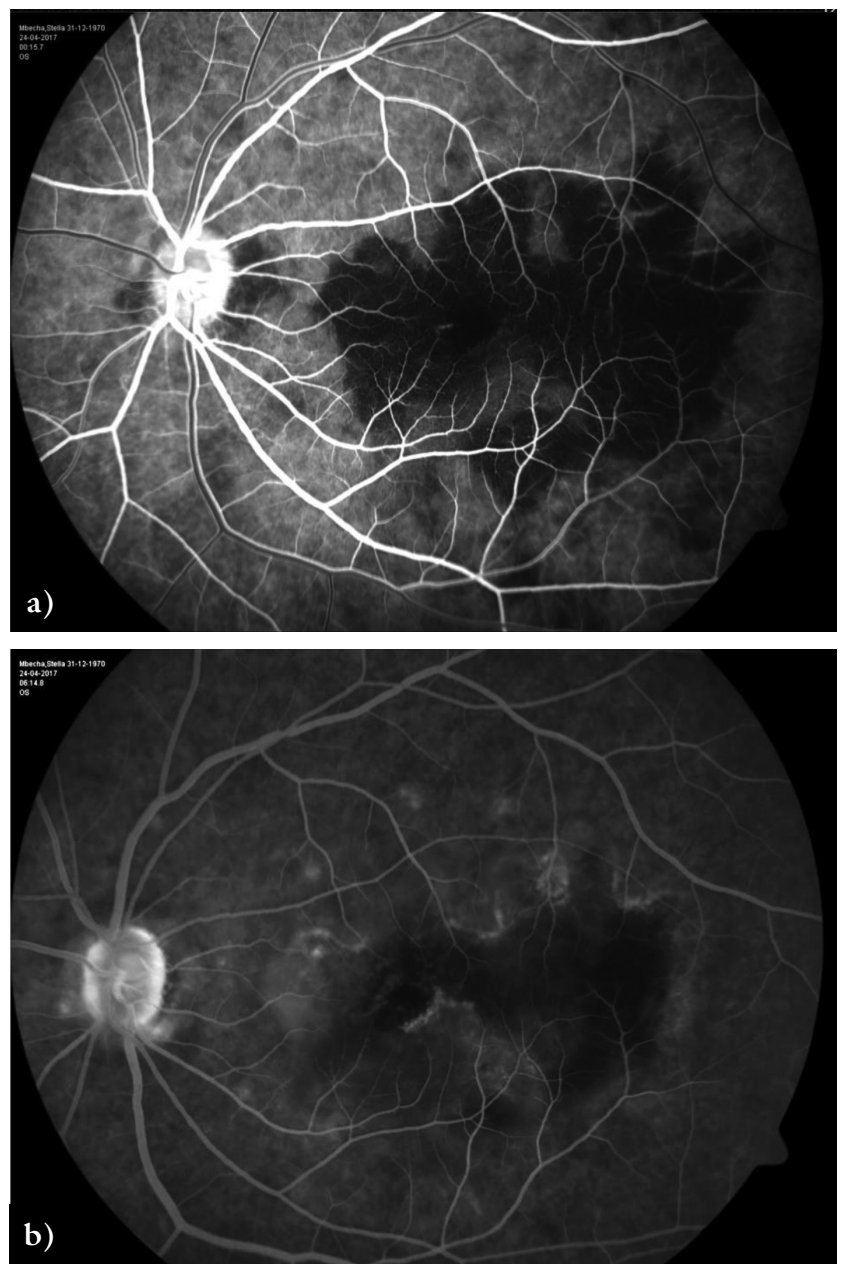

7. ábra

A fluoreszcens angiográfiás vizsgálaton a placoid laesiónak meg felelően hipofluoreszcens blokkolást a), szélein a későbbi felvé teleken hiperfluoreszcens festődést $\mathbf{b}$ ) figyelhetünk meg

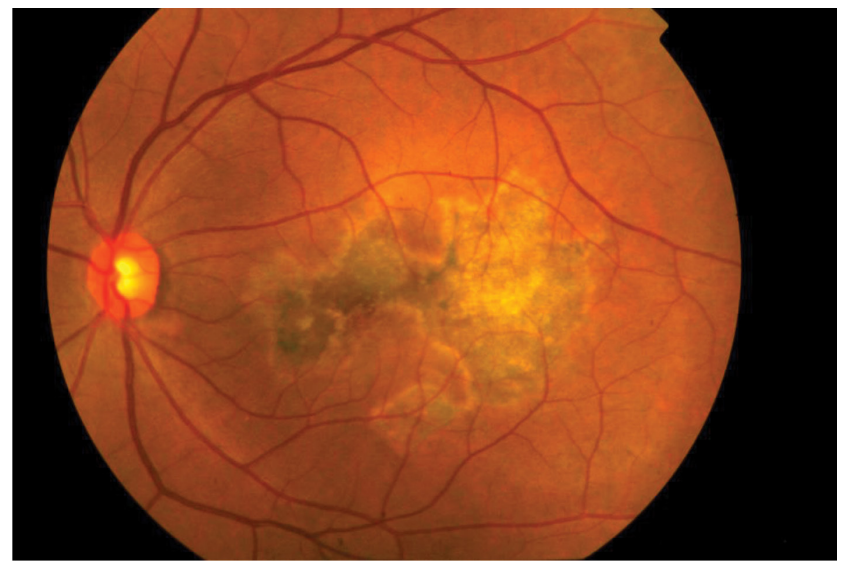

8. ábra

Két hónappal az antituberkulotikumos terápia megkezdését követően a szemfenéki képen a korábbi aktív placoid laesiónak megfelelően éles szélű, pigmentzavaros, atrophiás terület látható

dését követően a beteg látóélessége javult $(1,0 / 0,5)$, a szemfenéki képen a korábbi aktív placoid laesiónak megfelelően éles szélü, pigmentzavaros, atrophiás terület volt látható (8. ábra). A macula OCT-vizsgálata a subretinalis folyadék jelenlétét már nem mutatta, ugyanakkor a fotoreceptorréteg töredezettsége ábrázolódott (9. ábra). 


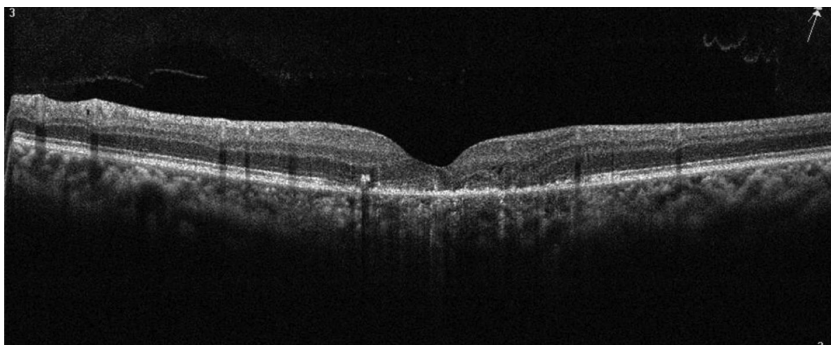

9. ábra

Két hónappal az antituberkulotikumos terápiát követően a ma cula-OCT-vizsgálaton a subretinalis folyadék mát nem látható ugyanakkor a fotoreceptorréteg töredezettsége továbbra is meg figyelhető

\section{Megbeszélés}

Az ocularis szifilisz és tuberkulózis a szemgolyónak és függelékeinek csaknem összes részét érinthetik.

A szifilisz szexuális úton terjedő, idült lefolyású fertőző multiszisztémás megbetegedés, amelynek szemészeti manifesztációi változatosak lehetnek. A 15 és 49 év közötti korosztályban globális prevalenciája 0,5\%, 2012ben 5,6 millió új esetet regisztráltak a világon [3]. Magyarországon 2005 óta stagnálást figyelhetünk meg az évente regisztrált új szifiliszes fertőzések adataiban [4], 2015-ben összesen 617 új esetet jelentettek hazánkban [5]. A szifilisz gyakorisága ezzel szemben világszerte emelkedő tendenciát mutat, főként a fejlődő országokban, ahol a szexuális úton terjedő fertőzések a fiatal férfiaknál az első öt leggyakoribb betegség közé tartoznak, míg fiatal nők esetében a második helyet érik el [4].

A napjainkban mindennapossá váló globális migráció és a szexuális szokások változása miatt minden orvosnak fel kell készülnie Európában és hazánkban is régi infekciók fellángolására, ismételt és gyakoribb megjelenésére. Magyarországon a fejlett diagnosztikus, szürési rendszer, az önkéntes alapon kérhető szerológiai szürővizsgálatok, a betegek felvilágosítása és a különböző orvosi szakterületek jó együttmúködése hozzájárulhat ahhoz, hogy a szifiliszes megbetegedéseket korai állapotban felismerjük és kezeljük. Ehhez azonban minden orvosnak ismernie kell a lues változatos klinikai tüneteit, köztük a gyakori szemészeti tüneteket is, amelyeket összefoglalva ismertetünk jelen közleményünkben.

A szifilisz kórokozója a Treponema pallidum nevú baktérium, mely a bőrön és nyálkahártyákon lévő apró sérüléseken keresztül jut a szervezetbe, és hematogén terjedés útján kerül a szembe. Átvitelének módja történhet a magzati életkorban (kongenitális forma) és felnőttkorban (szerzett forma). A kongenitális szifilisz, amely anyáról magzatra transzplacentárisan terjed, a leggyakrabban interstitialis keratitis formájában jelentkezik, amely az úgynevezett Hutchinson-triász részét képezi a süketség és a fogfejlődési zavarok mellett. A szemet érintő gyulladásos folyamatok nemcsak születéskor, de akár egy évtizeddel később is diagnosztizálhatók, mint „késői kongenitális" forma, ebben a stádiumban azonban már az idegrendszeri (progresszív paralízis, halláskárosodás) és az ízületi károsodások (Clutton-ízület) tünetei dominálnak [6].

A betegség szerzett formájában a szem csaknem bármely része érintett lehet, de a leggyakoribb szemészeti szövődmény az esetek körülbelül 10\%-ában létrejövő panuveitis, amely az uvea minden részét (szivárványhártya, sugártest, érhártya) érintő gyulladás, és a szifilisz bármely stádiumában előfordulhat. Az elsödleges szifilisz 3-6 héttel a fertőzés után jelentkezik a baktérium behatolásának kapujában kialakuló sánker, valamint regionális lymphadenopathia formájában. A másodlagos szifilisz 6-10 héttel az elsődleges fertőzés után alakul ki, és főleg generalizált maculopapulosus kiütések és lymphadenopathia jellemzi. Szemészeti eltérések ebben a stádiumban fordulnak elő a legtöbbször. Az elülső szegmentum szifiliszes gyulladása során keratitist, granulomatosus „szalonnás” vagy apró, nongranulomatosus precipitátumokat, hátsó synechiákat, irisatrophiát láthatunk. A hátsó szegmentum gyulladásakor vitritis, chorioretinitis, perifériás nekrotizáló retinitis, papillitis és neuroretinitis a leggyakoribbak. Harmadlagos szifilisz körülbelül 3-15 évvel a kezdeti fertőzés után alakulhat ki, és három további típusát különböztetik meg: gummás szifilisz (15\%), késői neuroszifilisz, amely a központi idegrendszert támadja meg $(6,5 \%)$, és szív- és érrendszeri szifilisz (10\%). Harmadlagos szifiliszben 2,5-3\%-ban fordul elő uveitis. Neuroophthalmologiai eltérések viszont erre a stádiumra jellemzőek: Argyll-Robertson-pupilla, optikus neuropathia, retrobulbaris neuritis, nervus oculomotorius bénulás [7].

Elsőként de Souza és munkatársai ismertettek három, szokatlan centrális chorioretinitis formájában megjelenő szifiliszes esetet [8]. 1990-ben Gass írta le először a szifiliszes placoid chorioretinopathiát (ASPPC) [9], amelyre a hátsó pólust magában foglaló, szoliter vagy multifokális sárgás színű placoid laesio jellemző a retina külső rétegeiben. Első esetünkben ez a szifiliszes placoid chorioretinopathia jelentkezett a szemfenéken. A betegnek a szemészeti tüneteken kívül egyéb panasza nem volt, és sem neurológiai, sem bőrgyógyászati eltérést nem találtak a társszakmák.

Ocularis szifilisz diagnózisakor HIV-teszt és neurológiai vizsgálat (liquorpunkcióval) elvégzése kötelező [10], mert ezen betegek 70\%-ban HIV-pozitívak [11], valamint a neurolues kizárása a későbbi terápia, szövődmények szempontjából fontos.

Az ocularis szifilisz diagnózisa a klinikai tüneteken túl a baktérium laboratóriumi tesztekkel történő kimutatásán alapul. A szerológiai tesztek specificitásuk alapján nontreponemalis (RPR-, VDRL-) és treponemalis (FTAABs-, TPPA-) tesztekre különíthetők el. A nem specifikus tesztek a betegség aktivitásának és a terápia hatásosságának követésére alkalmasak, és a kórokozó eliminálásával hamar negatívvá válnak, míg a specifikus tesztek a fertőzés lecsengését követően, akár egy életen keresztül is pozitívak maradnak.

$\mathrm{Az}$ irodalomban az ocularis szifiliszt a neurolues variánsának tartják, így kezelése is megegyezik annak a keze- 
lésével. A WHO jelenlegi terápiás irányelve szerint a betegség kezelése a szifilisz minden stádiumában naponta 18-24 millió NE kristályos penicillin G intravénásan történő adása (3-4 millió NE 4 óránként) 10-14 napig, majd hetente egy alkalommal intramuscularisan adott 2,4 NE benzatin penicillin $\mathrm{G}$, három egymást követő héten keresztül. Penicillinallergia esetén doxiciklin $(2 \times$ $100 \mathrm{mg} /$ nap 28 napon keresztül) vagy tetraciklin $(4 \times$ $500 \mathrm{mg} /$ nap 28 napon keresztül) szájon át történő adása, HIV-koinfekció esetén ceftriaxon (2 g/nap 10-14 napon keresztül) intravénás adása javasolt [12].

A szifiliszes betegek nagy jelentőséggel bírnak társadalmi szempontból is, hiszen a megbélyegzéstől való félelem, a család vagy állás féltése az igazság elhallgatására kényszerítheti a betegeket, pedig a fertőzési lánc megszakításának egyik alapja a sikeres kontaktuskutatás. Esetünkben bőrgyógyász, háziorvos segítségével a fertőzési lánc felkutatása is sikeresen megtörtént, a partnerek kezelésre kerültek.

A tuberkulózis extrapulmonaris megjelenési formái igen változatosak lehetnek, különösen a tuberkulózisendémiás területeken, így Afrikában, Dél-Ázsiában és Indiában. A WHO szerint a világ népességének közel 1 /3-a hordozza magában a tuberkulózisbaktériumot, 10\%-a tünetekkel rendelkezik, míg 90\%-ban tünetmentes fertőzés (látens tuberkulózis) áll fenn. A tuberkulózisfertőzöttek száma egyre növekszik a multirezisztens kórokozók, a biológiai terápiák (TNF $\alpha$-gátlók) alkalmazása, a HIV-fertőzöttek és a globális migráció miatt [13]. Magyarországon 2015-ben 918 új tuberkulózisesetet jelentettek be a tüdőgondozók [5]. Napjainkban az egész világot érintő migrációs hullám miatt várhatóan egyre nagyobb számban találkoznak az európai orvosok tuberkulózissal, és nemcsak a pulmonológusok, hanem más társszakmák képviselői is. Az ocularis tbc jellegzetességeit a következókben mutatjuk be, melynek diagnosztikája és kezelése a szifiliszhez hasonlóan mindenképpen interdiszciplináris összefogást igényel.

A betegség kórokozója a Mycobacterium tuberculosis nevú aerob baktérium, mely leginkább a magasan oxigenizált szövetekben fordul elő. A tuberkulózis leggyakoribb lokalizációja a tüdő (tüdőtuberkulózis). Az esetek $20 \%$-ában a betegség egyéb szervet érint (extrapulmonalis tuberkulózis) [14]. Korábbi tanulmányok szerint az intraocularis tuberkulózis előfordulása 1,4-18\% [15]. Az intraocularis érintettség általában szekunder módon, a baktérium hematogén terjedésének útján alakul ki, azonban a fertőzésre kialakult hiperszenzitivitási reakció és a baktériumnak közvetlenül a szembe való bejutása is szerepet játszhat a betegség kialakulásában [16]. A fertőzés leggyakoribb szemészeti lokalizációja az uvea, magas vérellátása és oxigenizáltsága miatt. Ritkábban a baktérium közvetlen bejutásának területén a fertőzés a szemgolyó és a szem függelékeinek egyéb részeit is érintheti, így a szemhéjakat, a conjunctivát és a sclerát [17]. Nem endémiás területeken, pl. Európában, leggyakoribb intraocularis megjelenési formája a granulomatosus uveitis és panuveitis, de chorioidea granuloma, chorioidea tuberculoma, multifokális serpiginoid chorioidits és serpiginosusszerú chorioiditis formájában is megnyilvánulhat. Az ocularis tuberkulózis endémiás területeken gyakran jelenik meg serpiginosusszerú chorioiditis (SLC) formájában, melyet második esetünkben ismertettünk, és patomechanizmusában a kórokozó hatására kialakuló hiperszenzitivitási reakciót valószínúsítik [16].

A klinikai kép változatossága és a diagnosztikus kritériumok irányelvének hiánya miatt az ocularis tuberkulózis diagnózisának felállítása gyakran nehézségekbe ütközik. Az anamnézis felvételén és a szemészeti vizsgálatokon kívül további laboratóriumi és képalkotó vizsgálatok elvégzése szükséges. A szemészeti érintettséggel rendelkező betegek nagy részében nem szerepel pulmonalis vagy egyéb extrapulmonalis érintettség az anamnézisben [18]. A tuberkulózis endémiás területeken való tartózkodás, ezekről a területekrőll történő migráció és tuberkulózisfertőzött személyekkel történő kontaktus (mint második esetünk mutatta) egyaránt a betegség predisponáló tényezői. Egyes esetekben a kontaktus évekkel a szemészeti tünetek kezdete előtt történt [19].

A tuberkulin-börpróba, másnéven Mantoux-teszt tisztított fehérjederivátumot (PPD) intradermalisan alkalmazva késői típusú (IV.), sejt mediálta reakcióval mutatja ki a fertőzést, alkalmazását azonban alacsony specificitása és szenzitivitása korlátozza. Korábbi BCG-oltás és atípusos mycobacteriumokkal történő találkozás álpozitív eredményt, míg az immunrendszer csökkent múködése álnegatív eredményt adhat. Ezzel szemben a T-sejt-alapú interferon-gamma-teszt - hazánkban QuantiFERONTB-Gold-teszt - magasabb specificitású, a vérből a baktérium antigénjeinek hatására kialakult gamma-interferonok kimutatásával igazolja a fertőzést, azonban gyakorlati alkalmazását korlátozza költségessége és eszközigényessége. Tuberkulózis gyanúja esetén anteroposterior irányú mellkas-röntgenfelvétel vagy komputertomográfia $(\mathrm{CT})$ elvégzése szükséges a tüdőérintettség igazolására, azonban a pulmonalis érintettség hiánya nem zárja ki az ocularis tuberkulózis lehetőségét. Korábbi tanulmányok szerint az esetek $60 \%$-ában nincs a betegnek tüdóérintettsége [18].

$\mathrm{Az}$ intraocularis tuberkulózis általában valószínúsített diagnózis, felállitásához nincs nemzetközileg elfogadott irányelv. A szemészeti kép és a laboratóriumi vizsgálatok alapján Gupta és munkatársai [20] a kórkép diagnózisát valószínúségük szerint két kategóriába sorolták. Biztos a diagnózis, ha legalább egy jellemző szemészeti klinikai tünet mellett a kórokozó kimutatható intraocularis folyadékból mikrobiológiai vagy PCR-vizsgálattal. Valószínú a diagnózis, ha legalább egy szemészeti klinikai tünet mellett képalkotó és szisztémás laboratóriumi vizsgálattal tuberkulózisra jellemző eltérés mutatkozik, vagy egyéb uveitis entitások kizárása és pozitív terápiás válasz esetén.

Az ocularis tuberkulózis kezeléséhez a szemész és a pulmonológus szoros együttmúködése nélkülözhetetlen. $\mathrm{Az}$ extrapulmonalis tuberkulózisok terápiája a tüdőtu- 
berkulózis kezelési protokolljának megfelelően, két szakaszban történik. Az intenzív szakasz 2 hónapon keresztül négy első vonalbeli antituberkulotikum (ATT) kombinációjának adásával kezdődik (izoniazid $5 \mathrm{mg}$ / $\mathrm{kg} / \mathrm{nap}$, rifampicin $10 \mathrm{mg} / \mathrm{kg} / \mathrm{nap}$, etambutol $25 \mathrm{mg} /$ $\mathrm{kg} / \mathrm{nap}$, pirazinamid $25 \mathrm{mg} / \mathrm{kg} / \mathrm{nap}$ ), majd ezt követően az utókezelési szakasz 4 hónapon át két antituberkulotikum (izoniazid, rifampicin) adásával folytatódik [21].

Eseteink érdekességét az adja, hogy jelenleg hazánkban viszonylag ritka, szisztémás fertőzések (szifilisz, tuberkulózis) csak szemészeti tünetekkel jelentkeztek, csak szemészeti manifesztációt okoztak a megszokott tünetektől eltérő módon; de a társszakmák bevonásával, konzultálásával sikeres volt kezelésük.

\section{Következtetés}

Cikkünkkel szerettük volna felhívni a figyelmet szifilisz és tuberkulózis esetén a szemészeti tünetek jelentőségére és az interdiszciplináris összefogás fontosságára, mert a betegek komplex diagnosztikája és kezelése így válhat teljessé. A szisztémás fertőzések megelőzésében és kezelésében a különböző szakterületek orvosainak együttmüködésére van szükség, hiszen a napjainkra jellemző társadalmi átalakulások miatt (például globális migráció, a homoszexualitás terjedése) fel kell készülni új, eddig hazánkban ritkán előfordult fertőzésekre, a védőoltásokkal korábban megelőzhető infekciók ismételt kialakulására, illetve új, ismeretlen manifesztációk létrejöttére.

Anyagi támogatás: A közlemény megírása, illetve a kapcsolódó kutatómunka anyagi támogatásban nem részesült.

Szerzői munkamegosztás: Sz. Zs., C. C., N. Z. Zs.: A vizsgálat tervezése. Sz. Zs., C. C., G. R., H. H., D J., K. I.: A vizsgálatok elvégzése. Sz. Zs., C. C.: A közlemény megírása. N. Z. Zs.: A közlemény kritikai revíziója. A cikk végleges változatát valamennyi szerző elolvasta és jóváhagyta.

Érdekeltségek: A szerzőknek nincsenek érdekeltségeik.

\section{Irodalom}

[1] Raven ML, Ringeisen AL, Yonekawa Y, et al. Multi-modal imaging and anatomic classification of the white dot syndromes. Int $\mathrm{J}$ Retina Vitreous 2017; 3: 12.

[2] Abu-Yaghi NE, Hartono SP, Hodge DO, et al. White dot syndromes: a 20-year study of incidence, clinical features and outcomes. Ocul Immunol Inflamm. 2011; 19: 426-430.
[3] Clinical advisory: ocular syphilis in the United States, 2015. Updated March 24, 2016 Available from: http://www.cdc.gov/ std/syphilis/clinicaladvisoryos2015.htm

[4] Pónyai K, Marschalkó M, Ackermanné SM, et al. Analysis of the patients with syphilis and gonorrhoea, on the basis of the National STD Centre, Department od Dermatology and Venerology, Semmelweis University (2005-2008). [Syphilis- és gonorrhoeaesetek elemzése, a Semmelweis Egyetem Bőr-, Nemikórtani és Bőronkológiai Klinika Országos STD Centrum adatai alapján (2005-2008).] Orv Hetil. 2009; 150: 1765-1772. [Hungarian]

[5] Sexually Transmitted Infections, Hungary, 2015 [Szexuális úton terjedő fertőzések, Magyarország, 2015.] Epinfo 2016; 23(1920): 229-239. (2016. május 27.). [Hungarian]

[6] Verghese VP, Hendson L, Singh A, et al. Early childhood neurodevelopmental outcomes in infants exposed to infectious syphilis in utero. Pediatr Infect Dis J. 2017 Nov 15. doi: 10.1097/ INF.0000000000001842. [Epub ahead of print]

[7] Lutchman C, Weisbrod DJ, Schwartz CE. Diagnosis and management of syphilis after unique ocular presentation. Can Fam Physician 2011; 57: 896-899.

[8] de Souza EC, Jalkh AE, Trempe CL, et al. Unusual central chorioretinitis as the first manifestation of early secondary syphilis. Am J Ophthalmol. 1988; 105: 271-276.

[9] Gass JD, Braunstein RA, Chenoweth RG, et al. Acute syphilitic posterior placoid chorioretinitis. Ophthalmology 1990; 97: 1288-1297.

[10] Wong T, Kropp R, Mann J. Canadian guidelines on sexually transmitted infections, 2006 edition. Public Health Agency of Canada, Ottawa, ON, 2006 [accessed: June 23, 2011].

[11] Blocker ME, Levine WC, St Louis ME. HIV prevalence in patients with syphilis, United States. Sex Transm Dis. 2000; 27: 53-59.

[12] WHO Guidelines Approved by the Guidelines Review Committee, WHO Guidelines fot the Treatment of Treponema pallidum (Syphilis). World Health Organization, Geneva, 2016.

[13] WHO global tuberculosis control: key findings from the December 2009 WHO report. Wkly Epidemiol Rec. 2010; 85: 69-80.

[14] WHO global tuberculosis report. World Health Organization, Geneva, 2013.

[15] Sanches I, Carvalho A, Duarte R, et al. Who are the patients with extrapulmonary tuberculosis? Rev Port Pneumol. 2015; 21 : 90-93.

[16] Sharma A, Thapa B, Lavaju P, et al. Ocular tuberculosis: an update. Nepal J Ophthalmol. 2011; 3: 52-67.

[17] Varma D, Anand S, Reddy AR, et al. Tuberculosis: an under-diagnosed aetiological agent in uveitis with an effective treatment. Eye (Lond.) 2006; 20: 1068-1073.

[18] Abu El-Asrar AM, Abouammoh M, Al-Mezaine HS. Tuberculous uveitis. Middle East Afr J Ophthalmol. 2009; 16: 188-201.

[19] Al-Shakarchi F. Mode of presentations and management of presumed tuberculous uveitis at a referral center. Iraq Postgrad Med J. 2015; 14: 91-95.

[20] Gupta A, Sharma A, Bansal R, et al. Classification of intraocular tuberculosis. Ocul Immunol Inflamm. 2015; 23: 7-13.

[21] American Thoracic Society, CDC and Infectious Diseases Society of America. Treatment of Tuberculosis. MMWR Recomm. Rep. 2003; 52: 1-77.

(Szepessy Zsuzsanna dr., Budapest, Üllői út 26., 1085 e-mail: szepzsu@yahoo.com)

A cikk a Creative Commons Attribution-NonCommercial 4.0 International License (https://creativecommons.org/licenses/by-nc/4.0) feltételei szerint publikált Open Access közlemény, melynek szellemében a cikk nem kereskedelmi célból bármilyen médiumban szabadon felhasználható, megosztható és újraközölhető, feltéve, hogy az eredeti szerző és a közlés helye, illetve a CC License linkje és az esetlegesen végrehajtott módosítások feltüntetésre kerülnek. 